MAREK HENDRYKOWSKI

Institute of Film, Media and Audiovisual Arts Adam Mickiewicz University, Poznań

\title{
Reality as a feeling - a feeling as reality. On the film by Joseph Cedar, Footnote
}

\begin{abstract}
Aвstract. Hendrykowski Marek, Reality as a feeling - a feeling as reality. On the film by Joseph Cedar, Footnote. "Images" vol. XXV, no. 34. Poznań 2019. Adam Mickiewicz University Press. Pp. 57-xx. ISSN 1731-450X. DOI 10.14746/i.2019.34.04.

This analytical study by Marek Hendrykowski is an attempt to re-read one of the most valuable contemporary films of Israeli production, Footnote, written and directed by Joseph Cedar. The author paid particular attention to the specific way of conducting a seemingly dependent narration, skillfully combining the image of external reality with the sphere of thought and the feelings of the main character.
\end{abstract}

KEYwORDs: intelligentsia, tradition, personality, science, culture, contemporary life, narration, narrative, Talmud, message, memory, identity

Sell everything, borrow money in order to marry a scholar's daughter.

Jewish proverb

Contemporary Israeli cinema is growing in strength. It has gained more and more artistic rank over the last decade. There is a lot going on in Israel's film life. A group of talented producers, screenwriters, directors, cinematographers and actors has appeared, along with films that remain memorable and bring new themes and a new look at the life in the country. I have not been able to watch all of them, but the ones I have seen so far do credit to the aspirations of modern Israeli cinema.

I mention, for example, Campfire (2004) and Beaufort (Silver Bear at the Berlin International Film Festival, 2007), directed by Joseph Cedar; the Oscar-nominated, Golden Globe-winning Waltz with Bashir (2008) by Ari Folman; Lebanon (2009) by Samuel Maoz; Policeman (2011) by Nadav Lapid; Youth (2013) by Tom Shoval; Cupcakes by Etan Fox; the comedy Big Bad Wolves (2013), directed by the duet Aharon Keshales and Navot Papushado; Norman: The Moderate Rise and Tragic Fall of a New York Fixer (2016) by Joseph Cedar; Scaffolding (2017) by Matan Yair; The Cakemaker (2017) by Ofir Raul Graizer; and the latest, premiered only last year, Foxtrot (2018) by Samuel Maoz.

The following article is entirely devoted to the analysis and interpretation of one film. It could have been, let us say, Graizer's The Cakemaker, Scaffolding by Yair, or Foxtrot by Maoz. However, I have chosen another film to discuss the matter in the form of a separate analytical study. It is a slightly older title, well-known in its time, i.e.
Images vol. XXV/no. 34

Poznań 2019

ISSN 1731-450X

Introduction 
in the 2011-2012 film season: Footnote directed by Joseph Cedar.[1] It has been chosen, first of all, because this work meets, in my opinion, the basic criterion for the risk of advanced originality of the subject, addressed in conjunction with the depth of its approach.

\title{
Intelligentsia
}

Let us start very unusually. It is said that what is intelligentsia and what importance it has as a phenomenon of social life does not need to be explained to Russians and Poles. A third nation must be added to this - both short and elite - list of insiders: Jews, for whose spirituality the phenomenon of the existence of the social class called "intelligentsia" is equally important. However, the French, British, and especially Americans clearly have problems understanding its specificity. A look at French and English dictionaries is enough to immediately notice the troublesome non-translatability of the very concept and the existence of this lexical and cultural confusion.

Any comparative reflection on the culture includes both a moment of analogy and a closely-related moment of difference. In the early 1930s, an outstanding Polish sociologist and cultural anthropologist, Stefan Czarnowski, wrote about it as follows:

\begin{abstract}
The comparison of human societies known to us and the cultures created by them forces us to give up once and for all the idea that we are dealing with peoples standing at different levels of one ladder. Although the state corresponds to, as we shall see below, the various schematic stages of change, nevertheless, in each case we face the fruit of the individual development. Every people, every culture is something individual, created by individual history. Therefore, we cannot present the states in which we find various peoples as the elements of one, common to all, historical development. If we could at least assume for one moment that different peoples, different cultures originate from one beginning! We could set ourselves the goal of the final sketching of the history of diversity and intersection at different times and in different places of these branches that have emerged from one stem. One could aim at, if not history in its strict sense in the face of the impossibility of establishing any chronological or absolute divisions, then at least at the genealogy that is not only racial but also cultural for particular human groups. One could even, based on the so-called obsolete, try to do something more, namely, to recreate in a most general way the path that particular developments had progressed before they reached the present state.[2]
\end{abstract}

[1] Director, screenwriter and film producer Joseph Cedar was born on August 31, 1968 in an orthodox Jewish family. At the age of six, after his parents had moved to Israel, he lived in Jerusalem, in the Bejit We-Gan district. During his school days, he still was strongly influenced by orthodox education. After completing his secondary school education and military service in commando units, he took philosophy and theatrology course at the Hebrew University in Jerusalem, then moved to New York, where he broadened his knowledge of cinema and film art while studying at New York University. As a 32-yearold filmmaker, he drew attention to hisdebut feature film, entitled $\mathrm{Ha}$-hesder (2000). Four years later, he became well-known, due to the five Israeli Film Academy Awards he received for "Campfire" (original title Medurat Hashever, 2004). Today, having made several more high-profile films, Cedar is one of the world's most famous Israeli filmmakers.

[2] S. Czarnowski, Założenia metodologiczne w badaniu rozwoju społeczeństw ludzkich, [in:] idem, Wybór pism socjologicznych, Warszawa 1982, p. 14. 
The identification and differentiation of traits linking different cultures usually reflects certain aspects of reality, but does not provide scholars with any basis for treating the classification itself as something real. In his article, deeply aware of the existence of this crucial border, Czarnowski writes about it as follows:

Explanation of the facts, to which the identification and distinction of features is an introduction, is an operation of the cognising mind, and not something given. Only phenomena are given. We distinguish them, group them, arrange them into series depending on objective features, but we choose them depending on the state of science - our science, not reality.[3]

Let us try to connect this still valid sociological and psychosocial reflection by Stefan Czarnowski, not accidentally quoted, to the film that interests us. Well, this above-mentioned conviction exactly corresponds to the issues dealt with by Professor Eliezer Shkolnik, to which we will return when creating the characteristic of the hero of Footnote. However, it is now worth noting that a special kind of philological, textual and comparative specialty and the circle of research interests of the film's protagonist which focuses on the diversity of source texts studied by him for decades plays a fundamental role in his film portrait, which is more important than it may seem.

Talmud scholar Eliezer Shkolnik is a researcher, philologist and humanist of a rare, not to say endemic, genre. He does not guard or strengthen the canonical version of the studied books. On the contrary, he sees and explores the richness of different versions and the differences spotted in them. This, in turn, makes him not so much a scholar of a narrow specialisation as someone who is a scholarly humanist with a broad view of the subject of his own research and of the sense of many years of intense study that is not obvious for the general public. Let us add that this occupation makes the learned philologist someone, so to speak, detached from the realm of prosaic benefits of life practice - an educated person with the "head in the clouds" of sublime research and knowledge.

In the societies of the western world, which are concentrated on the constant multiplication of wealth, the concept of "intelligentsia" does exist, but it has a different sense when attempting to explain it. It is far different from what we deal with in Central and Eastern Europe; it is deprived especially of certain aspects that are characteristic of it and incomparably more pragmatic in the applications expected by the general public. This observation will become a convenient starting point for us in the course of further reflections on the film Footnote when we deal with the environment that has been portrayed in it.

It is worth asking oneself: where does the action of Footnote

Place of action take place and in what specific sceneries has it been set by the author of the film? The list of these places starts with Rehavia, a quiet housing

[3] Ibidem, pp. 15-16. 
estate of Jerusalem, with its suburban tranquillity and narrow empty streets, where Professor Eliezer Shkolnik walks to work every day with a backpack.

But this is not the end. The rest of the scenery that we watch on the screen is equally important. The magnificent edifices of the Hebrew University of Jerusalem and its modern spacious library, as well as the Israel Museum and the stately auditorium hall, where the academic Israel Prize ceremony is to be held, are linked by the same ultramodern architectural style, to put it in a nutshell: big glass panes, steel reinforced concrete, monolithic surfaces of walls and floors; in short, ascetic minimalism. This is contrasted only with two other basic places in the life of the scholar: the professor's home studio that is stacked with books, and the back of the library at the university, where Shkolnik celebrates the news about the prize in the closeness of his friend.

I would add one more important element to this characteristic, namely the music to Footnote, as composed by Amit Poznansky. Does it have anything to do with the set design? Its programmatically amelodic style brings to mind "difficult" compositions by Prokofiev or Hindemith. But that is not the point. As a result of the functionalization of the sound sphere intended by the creators of the film, subsequent appearances of the musical layer perform a function not so much musical as purely sonic, and it becomes on the screen something in the shape of a sophisticated sound setting.

The cold style of the screen scenery, which has been described and consistently maintained by the creators of the film, corresponds in a sophisticated manner with the sense of alienation of the hero. This style, by means of visual empathy, affects the viewer scene by scene. The images of the filmed reality serve to express the state of the hero's spirit by extracting dissonances. Reality changes into a feeling. The architecture used in Footnote functions on the screen as a medium and a specific counterpoint of individual spirituality.

Eliezer Shkolnik moves around in this world as if in a completely unknown, foreign land. Although he knows "his own" places, paths and roads, because he takes them every day, in our eyes, he is someone deeply alienated, chronically separated from his surroundings and environment, existing in a different dimension: text, logos, learned books, mental abstraction, scholarly investigations.

Let us add that although the action of Footnote is taking place from the beginning to the end in modern times, in the filmed image of the city there is no pulse of everyday life, bustle of streets, the atmosphere of life in a densely populated city centre etc. Jerusalem functions in Cedar's film as a material-spiritual reality presented in a specific way: a form of collective memory, tirelessly studied and cultivated by the hero, but also carefully stored by - traditionally feeling respect for the broadly understood wisdom - a society that understands the importance of the role of study for its comprehensive existence. 
The opening caption reads: "The most difficult day in Professor The Hero Shkolnik's life". We can see an older man in a jacket and a grey cap standing against a large bookcase full of books. The woman's voice asks off camera: "Are you going?" Having not received a reaction to the question, the woman leaves the house alone, slamming the door behind her. Then the male voice, acting as the host of the story, takes the narrative initiative, presenting, as it turns out, not the hero himself, but his son: "Professor Uriel Shkolnik, director of the Institute of Judaism at the Hebrew University, a long time lecturer at the Talmudic Research Department and a world authority in this field, laureate of many awards..."

We learn from the narrator's account that Professor Uriel Shkolnik has just been elected a member of the Academy of Jewish Research in New York. However, we are under the impression that it is all about his father. All this information reaches the viewer in the consciously assumed cognitive dissonance of the narration, along with the image of Eliezer's wife waiting in a taxi. Finally, Shkolnik senior leaves the house, which we can see through the window of the car; however, he does not get in, but he starts walking quickly forward. The woman gives the driver the address: the Israel Museum.

This simple, opening scene contains the succinct character of the film. The main hero of Footnote is not Uriel, whom we will meet later, but someone else: a retired man, an employee of The Hebrew University of Jerusalem: Uriel's father, Professor Eliezer Shkolnik. It is impossible to call him an aged man; he is rather in his sixties or seventies, in the prime of life, but before the impending transition to a state of academic retirement, and old age is just about to come. From the first scene of the film, we visit the scholar's home personally, and we know in what environment (a lot of books on the shelves, piles of files with thousands of notes tucked away in cupboards) and in what conditions he lives, what his life rhythm looks like.

Incidentally, additional reflexes to the figure of the main character are brought by the meaningful surname that the screenwriter invented for him. It sounds like Shkolnik. The word "shkolnik", known in Yiddish, means "a student" in Russian. The word "shkolnik" is also perfectly understandable in Polish, although in colloquial Polish it sounds slightly ironic and detached, somewhat akin to the word "schoolkid". The family of Shkolniks - Eliezer (father) and Uriel (son) are professionally involved in lecturing, instruction and teaching.

Cedar's film story generally does not contain retrospective scenes, but the narrator, if necessary, occasionally evokes important images from the past of both scholars. In the memory of Uriel, Professor Eliezer Shkolnik, the patriarch of the family, instilled in his 8 -year-old son that the proper expression of the father's profession is the word "teacher". This anecdote, which is a part of the laudation given in honour of the father, is accompanied by an ironic conclusion: 
"Today I know that a lecturer at the university is not something that children boast about."

Note, however, that Shkolnik the father - a senior lecturer at the Talmudic Research Department of the University of Jerusalem, an outstanding specialist in the field of Judaic studies - when cornered about the necessary self-determination of the profession, will finally call himself a "philologist". It is worth noting that the ancient Greek origin of this complex expression means both a researcher of verbal texts and someone who is passionate about the sphere of logos, a lover of the word, aware of its importance and the significance of meaning.

Dramatis personae

Up to now, the protagonist of Footnote has been discussed. Professor Eliezer Shkolnik - a fictional, just like the remaining characters, doyen of Israeli philology - is more than just a standard protagonist of the contemporary film, a typical persona dramatis in the function of the central figure. As the story unfolds, we realize that he plays in it a highly significant function of the medium through which we view, perceive and feel the world in which this person lives.

In this respect, Footnote by Joseph Cedar presents the unique value of a work of considerable cognitive value: in a precise way presenting the complex reality of the scholar's life and the morphology of the academic world that is hard to access and even harder to display on the screen.

This academic world is not homogeneous. It consists of a variety of different planes, each of which brings something relevant to the overall picture. Let us try to briefly list the most important of them. We have here: the intimate plane of prosaic existence in the comfort of the family (in the Shkolniks' house, there are three generations under one roof: grandparents, parents and grandchildren), the plane of everyday life of an outstanding scholar, the plane of academic classes and the routine of university life, the mechanisms and behind-the-scenes activities of the board of a prestigious academic prize (together with all the returns, corrections and deletions while writing the justification). And finally, the "external" picture of academia reflected in the media (interviews for the press and television) and in the solemn form of the annual ceremony of awarding the honourable state prize, or rather the sequence of the final rehearsal which precedes this ceremony.

Eliezer Shkolnik's antagonist is his opponent, Professor Grossman, who has extensive influence in the academic community. He has access to the collection of manuscripts and can effectively harm his competitors. He has hated and disregarded the outstanding researcher for years. It is he who destroys Shkolnik's academic career, hampers promotion, and blocks the awarding of the prize and the election to the Israeli Academy of Sciences for a quarter of a century. Several other supporting characters (son, wife, daughter-in-law, granddaughter, grandson, fellow professors, journalist, chapter members, bodyguard 
protecting the entrance to the ceremony and others) together create an environment that is something like the ecosystem of the professor's life.

An extremely important narrative function is, however, performed not by the antagonist Grossman, but by Professor Shkolnik's son Uriel.[4] This character's construction is an example that shows the artistry of Cedar's film narration, which makes each of the portrayed people in the drama experience a change that we can witness. This way they deepen and enrich their screen image. They all turn out to be ambiguous, so that the story gains immensely in the richness of its meanings.

The structural system of Footnote is determined by a specifically designed relation of tensions between the plot and the narration. Both orders remain in the intended permanent conflict. While the story of this film has a somewhat simplistic shape, the way the narration is conducted has a broad and sophisticated character. In the simplest terms: there is little fictional inventiveness here (the multiplication of different types of twists and turns) in contrast to the awe-inspiring, and for a certain category of viewers, very attractive, finesse and narrative refinements.

At the base of the simple plot lies the qui pro quo (the institutional sender confuses the recipients of official correspondence: father and son, professors Eliezar and Uriel Shkolnik). Thousands of screen stories are also based on qui pro quo constructions. We are used to the fact that they become something funny. Whenever someone is mistaken for somebody else, it gives more reason for comedic situations that cause laughter, but not in the case of Footnote.

Instead of comedy, in Cedar's film there is a human drama in which there is nothing to laugh at (Uriel says to his friends about his father: "To take away this joy from him is a crime!"). In the sequence of the clash between Shkolnik junior and his father's antagonist Grossman, we become witnesses to the obvious harm and irreparable damage caused to the distinguished scholar. Interestingly, this harm - as we learn during the meeting of the award committee - has been intended by the malicious chairman, Grossman. Qui pro quo in the form of the unfortunate phone call to Eliezer Shkolnik is therefore not anyone's intrigue, but a fatal result, the proper cause of which lies somewhere else.

Let us repeat that this type of plot construction is usually used by comedy films, and qui pro quo drives the course of action in a variety of ways. In this case, however, we are dealing with a deeply dramatic

[4] It is also important that Uriel Shkolnik is the first-born son of Eliezer. In the Jewish tradition, the first-born son is a special figure for his father. Primogeniture gives a special status to the oldest of the sons, as mentioned in the Mishnah. It must not be forgotten that in the case of tense relationships in this family, a deep conflict between father and son
The structure of the narration manifests itself, and in the wider context also between grandfather (Eliezer), father (Uriel) and grandson, who sponges off his family. It is also important that it is a family of scholars. The Sanhedrin's treaty regarding academia and the principles that should govern it says: "Man does not envy only his son and disciple." 
qui pro quo. We observe the inner drama, full of suffering and personal harm, of a person who once again in their lifetime has been overlooked. However, this time, the careless secretary is the involuntary "perpetrator", but the beneficiary of the "mistake" in the form of awarding the prize is not a stranger, but his own son, which makes the whole situation even more bitter and unbearable.

The mode of narration
At first glance, the narration used by Footnote is nothing but the use of the mode of so-called objective narration, which would be much better and more correct to define as an objectivising narration. This mode is introduced by the author in the first scene: a description of the scholar's daily routine in the morning, additionally reinforced by the caption: "The most difficult day in Professor Shkolnik's life". This conclusion, seemingly legitimate, turns out to be completely erroneous and misleading.

The mode of narration used in the film Footnote is geared from beginning to end towards showing the spirituality of an individual as a complex process of the main character's inner life, which is based on disharmony with the world. In order to achieve this effect, Joseph Cedar decided to tell the story of Eliezer Shkolnik in a way that is as formally uneven as it is unconstrained. We have here a range of narrative tricks, including an off-camera narrator, the author's commentary appearing in both intertitles and, formerly rare but today more and more common, inset titles (the enunciations appearing on the screen, such as "A handful of information about Eliezer Shkolnik").

Next, there is the parallel action editing (Uriel writing the justification of the prize, which is edited alternately with the interview given by his father). There are also numerous inversion devices, introducing necessary suspense to the development of the story. This boldness and the openness strictly connected with it brought a surprisingly good and resounding result in the form of a splendidly conducted discourse on life, the sense of existence, the importance of truth ("one does not cite stray evidence", says Eliezer Shkolnik to his grandson). I consider the discursiveness of Footnote as a great artistic and cognitive advantage of this film. It has been achieved by linking the chosen mode of narration with the construction of the main character.

Professor Shkolnik's personality has been shaped by years of everyday personal contact with the holy books of the Jewish people. I emphasize the adjective "personal", because this contact led to the fact that in the world and the reality surrounding the scholar there has never been anything more important than the truth of the books that he has studied. He, the guardian of tradition, the researcher of its written message, the right (i.e. reliable) shape of which is held in his mind and memory, comes into conflict with the museum's bodyguard, unable to comprehend the difference in contemporary understanding of the function of a guardian (read: bodyguard) of anything. This thought returns as a beautiful refrain in one of the last scenes of the film, when 
the laureate is putting out both hands at the entrance so that the guards of the ceremony can put on a wristband.

An extraordinary, fascinating display of the seemingly dependent narration performed by Joseph Cedar and the team of co-creators reaches its apogee in the final part of Footnote. On the day of independence of his country, Professor Eliezer Shkolnik arrives at the State Conference Centre of the Israel Museum in Jerusalem in order to receive the prestigious prize for all his academic achievements in the presence of the President, Prime Minister and the Speaker of the Knesset. After a while, we realise, however, that this is not the ceremony itself, but only its final rehearsal. The protagonist participates in it with a sense of deep alienation. He moves among alien, indifferent figures and takes part in only a hypothetical course of what is to take place. Visual and auditory images of reality on the screen are transformed into a stream of old scholar's thoughts and feelings. This stream of emotions is the only reality of the analysed work.

It is the time to verify the initial hypothesis regarding the theme of the film Footnote, which was put forward at the beginning of this study. On the basis of the deliberations contained in it, it seems that its proper theme is the restoration of the proper measure of the discussed matters that concern the sphere of values. This restoration is essentially cathartic. It means a symbolic agreement and the consent of the author of the film and his viewer to the mutual conviction that, in addition to what is current, scholars erect lifelong buildings of monumental importance to the life of the community, of which they are a distinguished particle.

So what would be, in the light of these considerations, the "intelligentsia" that was mentioned at the very beginning? It can be concluded that, in the context of the study presented, it functions not in one but in two - complementary to each other - meanings. The first of these is the sociological meaning that has been widely recognized for a long time. It is about the existence of a certain, not too large, social class that performs a broad repertoire and collection of various types of mental activities for the benefit of the society and serves its development.

The second of the meanings of the term "intelligentsia", by no means excluding the first one, encompasses a range of relationships that combine intelligentsia as a mission-equipped class of society with the service it performs for individual and collective wisdom. This is how Professor Eliezer Shkolnik understands the meaning and value of real scholarly activity. And that is why the ethos of research and the scholar's attitude are so important to him. In his busy life, learning, studying, inquiring, searching for the truth become a tireless cultivation of what is most valuable in social life, of what enables man and the community to last (tradition!) and to continuously develop (future!), while constantly multiplying knowledge and expanding the horizon of life. 


\section{8}

MAREK HENDRYKOWSKI

B I B L I O G R A P H Y

Cała A., Węgrzynek H., Zalewska G., Historia i kultura Żydów polskich. Słownik, Warszawa 2000

Chałasiński J., Przeszłość i przyszłość inteligencji polskiej, Warszawa 1958

Chałasiński J., Społeczna genealogia inteligencji polskiej, Warszawa 1946

Czarnowski S., Założenia metodologiczne w badaniu rozwoju społeczeństw ludzkich, [in:] S. Czarnowski, Wybór pism socjologicznych, Warszawa 1982

Hertz A., Żydzi w kulturze polskiej. Introduction by Cz. Miłosz, Warszawa 2004

Merton R., Social Theory and Social Structure, New York 1949. Polish translation:

Teoria socjologiczna i struktura społeczna, trans. E. Morawska, J. Wertenstein-Żuławski. Warszawa 1982

Ossowska M., Inteligent polski na tle grupy towarzyskiej Europy Zachodniej, „Myśl Współczesna” 1947, no. 5

Ossowska M., Podstawy nauki o moralności, Warszawa 1946

Ossowska M., Pojęcie moralności, „Etyka” 1966, no. 1

Polski słownik judaistyczny. Dzieje - kultura - religia - ludzie, vol. 1-2, ed. by

Z. Borzymińska, R. Zebrowski,Warszawa 2003

Shmeruk Ch., Historia literatury jidysz. Zarys, Warszawa 1992

Szczepański J., Inteligencja i społeczeństwo, Warszawa 1958 